Historic, archived document

Do not assume content reflects current scientific knowledge, policies, or practices. 



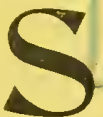

$\bullet$

\section{FOR FALL PLANTING AND SPRING FLOWERING}

\section{CALIFORNIA NURSERY COMPANY}

NILES, CALIFORNIA 1904.

\section{NARCISSUS}

TAZETTE

(WHITE PEARI, )

This variety is known as the Chinese Sacred Lily or bunch flowering Narcissus, and is grown extensively by the Chinese for use in their New Year festivals. Flowers are creamy white. Very fragrant and from I to $\mathrm{I} / 4$ inches across when expanded.

\section{5 cents per doz., $\$ 1,50$ per 100}

\section{CHINESE SACRED LILY}

A variety of Polyantlus Narcissus introduced by the Chinese. The flowers are pure silvery white with golden yellow cups, cliaste and graceful in appearance and of exquisite fragrance. The short time required to bring the bulbs into bloom (four to six weeks after planting) is one of the wonders of nature. 'They do reli in pots of earth, but are nore novel and beautiful when grown in sliallow bowls of water.

25 cents per doz., $\$ 1.50$ per 100

PAPER WHITE

The flowers are snow white, rery beantiful and enit a delicious odor. 'This is the earliest of all.

25 cents per dozen, $\$ 1.50$ per 100

POETICUS

The well-known Poet's Narcissus, a large and early flowering form. Petals white and cup tinged with orange.

25 cents per doz., $\$ 1.50$ per 100 


\section{BICOLOR HORSFIELDII}

Single pure white perianth with large golden yellow trumpet. Early.

25 cents per doz., $\$ 1.50$ per 100

\section{DAFFODILS \\ TRUMPET MAJOR}

A very large single yellow. This variety, richness of color and habit is too well known to need further recommendation.

25 cents per doz, $\$ 1.50$ per 100

\section{VAN SION}

The finest of all double yellow daffodils. Used extensively for forcing as well as for bedding outdoors.

- 25 cents per doz., $\$ 1.50$ per 100

PRINCEPS

Pale sulphur perianth, trumpet rich yellow, very showy.

25 eents ner doz.. $\$ 150$ per 100

\section{ROMAN HYACINTHS}

The flowers of this beantiful and very valuable variety are smaller than those of the ordinary hyacinth, but are produced in great profusion, each bulb throwing up three or four spikes of delicately scented, clear white blossoms.

50 cents per doz., $\$ 3.00$ per 100

\section{SINGLE JONQUILS}

Very popular flowers on account of their easy cultivation aud delightfully fragrant, golden-yellow blooms.

10 cents per doz. 75 cents per 100

\section{JONQUIL \\ CAMPERNELLE REGULOSUS}

The largest flowering jonquil. Pure yellow and very fragrant.

25 cents perdoz., \$1.50 per 100

GLADIOLUS

BYZANTINUS

Purple flowers, very early and rare. Hardy.

10 cents per doz., 75 cents per 100

For Spring Planting and Fall Flowering

AMARYLLIS=BELLADONNA

Rosy pink, rery fragrant.

5 to 6 incles in climurter, 5300 per 100

4 to 5 inclies ill diameter, \$2 50 pel 100; $\$ 12$ per 1000

3 to 4 inclies in dianeter, $\$ 2.00$ per $100 ; \$ 10$ per 1000 